\title{
МЕТАФИЗИЧКАТА ПОЕТСКА НИШКА ВО ПРЕПЕВОТ НА ПЕТРЕ М. АНДРЕЕВСКИ
}

\author{
Теа Дуза \\ Универзитет „Св. Кирил и Методиј“, Скопје \\ teaduza@yahoo.com
}

Овој труд се занимава со англискиот превод на еден од најпознатите македонски поети и романсиери Петре М. Андреевски. Анализирани се преводите на две негови песни, антологиската „Кога ја љубев Дениција“ и „Одаде и отаде“, со интерпретација на различните семантички нијанси помеѓу оригиналот и препевот (версификација). За таа цел е употребен моделот на Драги Михајловски познат како 'матрица на преводливост', со кој се прикажани отстапките на фонолошко, лексичко, синтактичко и семантичко рамниште. Секоја јазична отстапка е дискутирана а понудени и поткрепени се и нови преводни еквиваленти. Целта е да се прикаже преводот како креативен процес и бескрајна битка на преведувачот, особено при препевот. Во овој случај, се работи за препев на метафизичката нишка на избор песни од корпусот на Андреевски. Во потрага по подобри преводни решенија вклучен е и нов препев на наведените песни при крајот од трудот. Новиот превод е само уште еден обид да се пренесе естетската еквиваленција на оригиналот и да се преведе непреведливото во поезијата.

Клучни зборови: поезија, оригинал, препев, версификација, превод 


\section{THE METAPHYSICAL POETIC STRAND IN THE TRANSLATION OF PETRE M. ANDREEVSKI}

\section{Tea Duza}

Ss. Cyril and Methodius University, Skopje

teaduza@yahoo.com

This paper delves into the English translation of one of the most renowned Macedonian poet and novelist - Petre M. Andreevski. It analyses the translations of two poems, the anthological Making Love to Denicia and This Side and Beyond; followed by interpretations of the different semantic nuances between the original and the translation (versification). For this purpose, Dragi Mihajlovski's method known as 'map of deviation' is being used in order to present the deviations on a phonological, lexical, syntactic and semantic level. Each linguistic estrangement is discussed in details and new translation equivalents are offered and justified. The aim is to emphasize the creative process of translation and the never-ending struggle of the translator, especially in poetry translation. The paper revolves around the translation of the metaphysical elements in some of Andreevski's poems. In search of better translation equivalents, a new translation of the poems at hand is encompassed towards the end of the paper. The new translation is an attempt to reach the aesthetic equivalent of the original and to translate the untranslatable in poetry.

Keywords: poetry, original, versification, translation 


\section{1 Вовед: за преводот како креација}

Книжевниот превод е резултат на исклучително креативен процес кој е предизвик не само за преведувачот (кој храбро се нафатил на овој потфат однапред осуден на неуспех) туку и за јазикот на кој се преведува и кој се обидува да ја издржи тежината на светската литература. Велам неуспех, пред cè, бидејќ́ самата природа на јазикот нѐ ограничува, а при процесот на преведување од еден јазик на друг, значењето лесно се „лизга“, се слизнува по јазичните свиоци и попатно презема различни конотативни нијанси кои не би ги ни претпоставиле, а камоли превеле. Во книгата „Под Вавилон: Задачата на преведувачот“, Драги Михајловски расправа токму за јаловиот труд на преведувачот да го совлада оригиналот, и вели:

Светот е осуден на превод, човекот е осуден на превод, а преводот како процес, во суштина, ја искажува недостасаноста, незрелоста, несовршеноста, или просто, минливоста, менливоста и смртноста на светот и човекот во неа. Светот и човекот се, од самиот почеток, осудени како преводи да бидат неуспешни во сите свои активности бидејќи сѐ што прават никогаш не може да се заврши. Тие само преведуваат, а не можат ништо да допреведат. (Михајловски 2002: 18)

Да се тргне да се преведува од ваков координатен почеток е песимистички и обесхрабрувачки, но не и невозможно. Преведувачот, вооружен со зборови, јури кон оригиналот, свесен дека си има работа со бог (а сите знаеме дека смртник со бог не може); но кога преводот е добар, тој сепак успева за миг да го допре непреведливото, да чепне во невозможното. Ова особено важи за препевот како форма на превод, односно за теоријата на преведливоста на прозата и непреведливоста на поезијата.

Со својата збиена структура и јазична очуденост, каде што секој збор е симбол (и метафора), поезијата му ја дава на преведувачот улогата на Сизиф: тој мачно го турка, го искачува преводот кон врвот, се обидува да го постави на исто рамниште до оригиналот, го вага секој збор и кога ќе го одбере конечниот, секако, ќе згреши, а преводот ќе стркала удолу и ќе заврши во некој јазичен ќорсокак во кој тивко ќе го чека наредниот обид да си ги измерат силите. Она што преведувачот не смее да го занемари е дека тој мора да се стреми кон естетска, а не кон лингвистичка еквиваленција; преводот треба да ги предизвика истите чувства кои ги предизвикал оригиналот во времето на неговото создавање. Преведуваме смисла, а смислата не е во зборовите, таа ce наоѓa помеѓу нив, во празнината помеѓу стиховите (и речениците), во недореченото. Алудирам на она што германскиот критичар Валтер Бенјамин го нарекува намисленотио (герм.: das Gemeinte; англ.: the Intended object) и

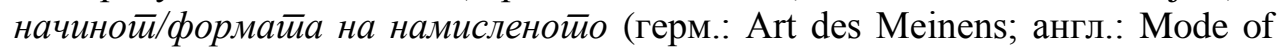


Intention), односно која е намерата на авторот и на кој начин го искажал намисленото.

Бенјамин ја развива оваа теорија во есејот „Задачата на преведувачот“ (англ.: The Task of the Translator) каде што вели дека: „Без разликување на

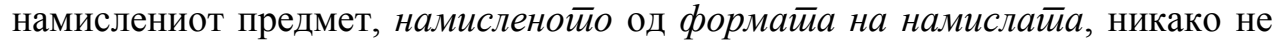
може сериозно да се сфати овој основен закон на филозофијата на јазикот“ (Бенјамин 1916). Есејот е напишан како предговор на неговиот превод на Бодлер (објавен во 1916) и станува алфа и омега на деконструктивистичката преведувачка школа на Дерида и Пол де Ман. Во есејот, Бенјамин го истакнува нивото на преводливост како еден од главните фактори за долговечноста на едно дело, неговиот суштински елемент кој мора да се пренесе на јазикот на кој се преведува. Уште на почетокот од есејот има цитат во кој Бенјамин се осврнува на неуспехот при преведувањето:

Но зарем не го сметаме најчесто за навистина суштествено во едно книжевно дело она што се содржи во него башка од информацијата - а ова и неумешниот преведувач го признава -недофатното, таинственото, 'поетското', она што преведувачот може да го пресоздаде само ако и самиот е поет? (Бенјамин 1916 во Михајловски 2002: 319)

Но, за жал (или за среќа), не секој преведувач е поет, ама настрана тоа. Клучно е да се посочи дека неизбежна особина на препевот (со сета своја загадочност) е неговата оригиналност. Колку и на прв поглед да звучи парадоксално (бидејќи препевот е рефлексија на оригиналот пренесена на друг јазик), тој сепак е длабоко херменевтички процес кој во себе подразбира толкување. Преку препевот, преведувачот ни нуди само една од можните интерпретации на оригиналот, па така, она што ние како читатели го добиваме е она што преведувачот го прочитал во оригиналот. И ова не важи само за поезијата како жанр, но тука е најистакнат тој јаз помеѓу преводот и оригиналот; па така, можеме да кажеме дека преводот претставува кршење на оригиналот, кршење на грчката урна на Китс и нејзино одново составување, кое можеби ќе ја зачува формата, но никогаш и значењето.

Овој труд е насочен кон толкување на ваквите отстапки од оригиналот при препевот (во случајов, на англиски), илустрирано преку примери од поезијата на македонскиот бард-Петре Мите Андреевски. За анализа се земени две песни, антологиската „Кога ја љубев Дениција“ и „Одаде и отаде“ од

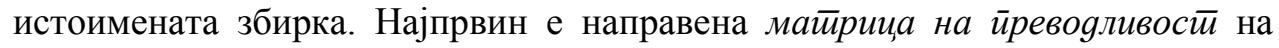
песните во оригинал, а потоа матрицата е поставена врз преводите за да се воочи кои очудености во јазикот на Андреевски се пренесени во препевот, и на кој начин отстапките во преводот создаваат нова интерпретативна нијанса што не ја среќаваме во оригиналот. Методот на правење мат̄рица на

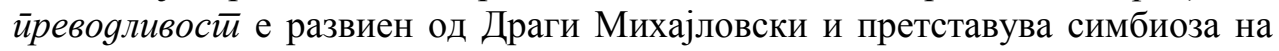
руските формалисти и на деконструктивистичката школа на Бенјамин Валтер и Пол де Ман. Целта на матрицата е да му помогне на преведувачот да ги 
препознае отстапките (очудувањата) или аграматикалностите на оригиналот за да може успешно и до детаљ да ги пренесе во преводот. Отстапките се разгледуваат на четири нивоа, и тоа на фонолошко, лексичко, синтактичко и на семантичко рамниште и токму во нив се крие стилот на авторот кој е еден од најголемите предизвици за книжевниот преведувач. На овој начин, преведувачот ќе го зачува ракописот на оригиналот со кој ќе му вдахне дух на преводот. Со ова се нагласува креативната природа на преводот, кој треба да се третира како авторско дело. Во потрага по нови и свежи преводни решенија, вклучен е и нов препев на песните при крајот од трудот. Свесна сум дека и мојот приод кон песните е само уште една можна нивна интерпретација, нова креација. Но пред сѐ, нужно е да споменеме збор-два за авторот и за неговите книжевни одлики.

\section{2 Петре М. Андреевски: Поет на архетипска имагинација}

Вака Ефтим Клетников го опишува Андреевски во поговорот на збирката песни „Никоја доба“ во која се наоѓаат и препевите (на избор песни) со кои за кратко ќе се занимаваме. Доколку го поставиме во временска/историска рамка, Андреевски ѝ припаѓа на третата генерација повоени македонски писатели во кои спаѓаат Влада Урошевиќ, Радован Павловски, Богомил Ѓ узел и ред други писатели меѓу кои Андреевски се издвојува со препознатлив ракопис. „Уште при појавата на неговите први книги од критиката беше забележано дека авторот донесува еден свеж, недопрен јазик, еден лексички фонд што доаѓ од доменот на народните раскажувачи и на народното пеење“ (Андреевски 1984: 18)

Она што плени кај Андреевски е метафизичката поетска нишка која безмалку се провлекува низ повеќе негови песни. Во неговото магиско обраќање препознаваме архаична, митска невиност, и една „конкретизирана микроглетка на хаосот [...], атрибутот што Лорка му го припиша на Гонгора, поет со микроскоп во зеницата.“ (Андреевски, 1988: 116). Ваквиот метафизички призвук додава спиритуален набој на неговата лирика, елемент кој се среќава и кај Џон Дан во англиската и кај Данте како метафизички поет во италијанската книжевност. Во циклусот песни „Дениција“, Андреевски креира калеидоскопски приказ на љубовниот субјект кој го прикажува од навидум неповрзливи агли кои асоцијативно ги проткајува, за на крај да ја воочиме сета нивна интуитивност и надреална логика кон кои се стремат. Па така, песните се секогаш некаде на полпат помеѓу јавето и сонот, земното и небесното.

Уште еден елемент кој вреди да се истакне е дихотомската поделба во неговите дела (велам дела бидејќи ја наоѓаме и во двогласјето на наративот преку Јон и Велика во „Пиреј“). Пример за ова се песните во „Дениција“ во кои се среќаваме со односот душа/тело и живот/смрт, испреплетување на 
Ерос и Танатос во еротски матрици кои постојано нѐ потсетуваат на смртта. Целта на дуалистичната поделба не е да се истакнат екстремите туку да се надмине границата на индивидуалното кое ќе се поврзе со метафизичкото, и ќе се сплоти во нешто ново, заедничко. Ова е особено истакнато во збирката „Дениција“ во која, како што вели Гане Тодоровски во предговорот:

Љубовта е овдека двигател, акција, сознание, радост, недостиг, патило, смрт. Стихот за неа носи мирис на наш збор, непристорен, изворен, темпераментен. Љубовта е овде и казна и неизвесност и очекување и понижување и конфликт и трагика и излет и полет и навик и говор на крвта и распоред на денот и виза за вечноста. (Андреевски 1991: 7)

Тука се наметнува прашањето: каква корист има преведувачот од сето ова? Одговорот лежи во она што Драги Михајловски (алудирајќи на рускиот

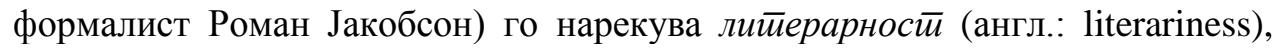
односно умейничкойо во едно дело: она по што препознаваме дека еден текст е Достоевски, или е Шекспир, стилот на авторот. Руските формалисти ставаат посебна нагласка на преведување на стилот бидејќ, според нив, таму лежи естетската вредност на авторот. Нивниот стремеж да ја постават книжевноста на научна основа подразбира детална анализа на поетскиот (естетскиот) јазик преку нивната главна алатка: очудување, во смисла на очудување на стварноста и нејзино одново создавање. Да погледнеме како (и колку) е постигнато тоа во песните на Андреевски.

Она што вреди да се напомене за збирката „Никоја доба“ е дека таа претставува збир на избор песни од неколку збирки на Андреевски: „Појавата на змијата“, „Кога ја љубев Дениција“, „Леунтија“, „Тркалезни форми“ и „Одаде и отаде“. Збирката содржи и преводи на мал избор од песни кои се препеани на англиски, француски или албански јазик. Во „Никоја доба“, корпусот на песни во англиски превод е скромен (само шест песни), а овој труд е насочен на интерпретација на метафизичката нишка во преводните решенија на две од шесте песни. За жал, во изданието на поетската збирка не е наведен ниту еден од преведувачите; ни тој на изборот песни преведени на англиски, ни на француски, ни на албански. Ваквиот пристап ја деградира улогата на преведувачот во пренесување на културното наследство од еден јазик на друг; а токму преведувачот треба да биде веднаш до авторот бидејќи го пренапишал, го пресоздал неговото дело и го загарантирал неговиот поживот во книжевноста на која го превел. Па така, немам кому да се заблагодарам за препевот на Андреевски кој ме поттикна да размислувам за преведувањето метафизика, за преведувањето космичка љубов, и во колкава мера таквиот подвиг е (не)возможен. 


\section{3 Кога ја љубев Дениција}

Во „Кога ја љубев Дениција“, првата замка се наоѓа уште во насловот, кој едновремено е и почеток на секоја строфа (со малку поразлична варијанта во четвртата). Повторувањето на стихот (како рефрен) прави ехо кое се нагласува, градира до самиот крај, и од Дениција создава една химна на љубовта во која се обединуваат сетилното и спиритуалното. Но, колку е ова очевидно и во препевот? Преводниот еквивалент на насловот ја проблематизира оваа двослојност на чувството и опфаќа само една негова димензија. Англиското to love би се превело како 'да сакаш' некого; а пак фразата making love алудира на физичка, сетилна љубов, што ѝ дава еротски призвук на песната. Со овој избор ние, како преведувачи, целосно ја лишуваме песната од нејзината метафизика и од неа го соблекуваме спиритуалното во кое Андреевски ја облекол.

Имено, оваа разлика се чувствува и во македонскиот глагол сака наспроти љууб; да љубиш некого подразбира многу поголем емотивен багаж отколку да сакаш. Па така, глаголот љубб дедуктивно ги повлекува и атрибутите: сака, обожува, почитува, восхитува и велича, но не може да се каже истото и за глаголот сака ('to love'). Згора на тоа, making love ('водење љубов') е излитена фраза која не се совпаѓa со свежите метафори на Андреевски, кој со романтичарски елан тргнал да ја опева љубовта (тој непресушлив извор во уметноста) и притоа вешто ги избегнал сите стапици на клишето во кои љубовта лесно преминува во патетика.

Како што и самиот Андреевски споменува во збирката, Дениција е наша учителка по дишење. Таа е и почеток и крај и одговор на прашањето: кој е човекот кога ќе го изгуби своето jac во допир со $\bar{u} u$; таа е копнеж кон свет на самостојност, таа е татковина. Самото име, Дениција, во себе го содржи името Деница, кај народот позната како звездата-чувар бидејќ е првата светла точка пред изгревот (и по залезот) на Сонцето; а инаку е планетата Венера, именувана според римската божица на убавината и љубовта, она што во грчката митологија е Афродита. Вака гледано, Дениција е божица, субјект на обожување, натчовечко доживување, муза. Она што е Беатриче за Данте, или Лаура за Петрарка, тоа е и Дениција за Андреевски, и тоа не може да се сведе на сака ('to love'). Од таа причина, тргнав да барам друг збор кој во себе би го понел ова божествено, метафизичко, спиритуално љубење во англискиот, а да не би било тоа сегашното making love во насловот и стигнав до глаголот adore ('обожува'). Ова преводно решение можеби за нијанса се оддалечува од првобитното физичко сака, но затоа пак во себе ја содржи смислата на двете, и сетилното и спиритуалното. „Зашто смислата, во своето поетско значење, не се ограничува на намисленото, туку произлегува од конотациите пренесени од зборот избран да ги изрази“ (Михајловски 2002: 323). Затоа сметам дека е оправдано насловот да биде Adoring Denicia”, за љубовта која постои во (најмалку) две димензии. 


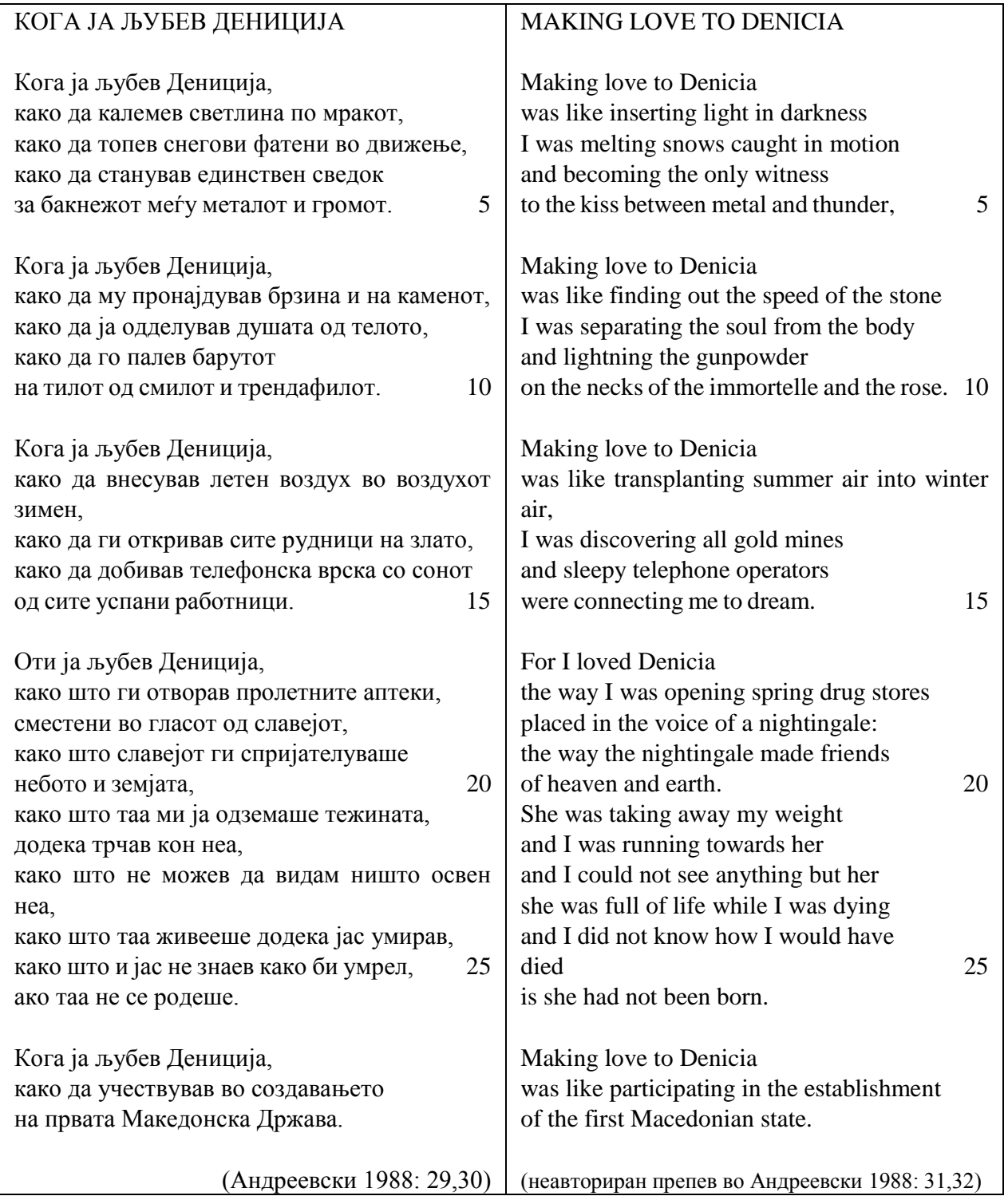

Да продолжиме со споредбите помеѓу оригиналот и препевот, овој пат на фонолошко рамниште. Музикалноста е една од главните одлики на поезијата и затоа е важно да се пренесе таа певливост и во јазикот на кој преведуваме (доколку не успееме во целост, барем во поголема мера и, секако, не по секоја цена). Во нашиов случај скоро и да нема рими, а сепак песната е ритмична. Андреевски го постигнал ова на неколку начини: пред сѐ, користејќ́ анафора. Покрај повторувањето на насловот на почетокот од секоја строфа, воочливо е и повторувањето на како ga (и варијацијата како шимо) со кое почнуваат 16 
од вкупно 29 стиха (што е повеќе од половина песна). Со како ga не само што се создава ритам, туку и се најавува нова споредба, нова метафора која се надоврзува на лајтмотивот на песната: љубовта кон Дениција.

Во препевот се забележува извесен ритам, а и дека преведувачот се трудел ама се нашол во небрано па отстапил од оригиналот и решил да користи четири варијанти за како ga: 'was like', 'I was', 'and' и 'the way'. Но и покрај флексибилноста која ја нудат четирите варијанти (наспроти две), тие сепак не се повторуваат подеднакво како во оригиналот, а со самото тоа што се различни форми се губи повторливоста и така се разводнува и севкупниот ритам на песната во препевот.

Покрај анафората, „Кога ја љубев Дениција“ изобилува со алитерација што, како стилска фигура, го прави јазикот поигрив на ниво на стих (или на строфа). Така во првата строфа е забележливо повторувањето на $\kappa:$ „како да калемев светлина на мракот“ (втор стих), с/в: „како да станував единствен сведок“ (четврти стих) и $м$ : „за бакнежот меѓу металот и громот“ (петти стих). Во втората строфа се повторуваат $g$ и $\bar{w}$ : "како да ја одделував душата од телото / како да го палев барутот / на тилот од смилот и трендафилот““ (стих 3-5). Во третата в: „како да внесував летен воздух во воздухот зимен“ (втор стих) и $c$ : „како да добивав телефонска врска со сонот“ (четврти стих), а во четвртата строфа $\bar{u}$ и $c$ : „како што ги отворав пролетните аптеки / сместени во гласот од славејот / и како што славејот ги спријателуваше“ (стих 2-4). Препевот не ги отсликува ваквите алитеративни венци: можна причина е што македонскиот јазик е во блага предност бидејќи правописот ни е поставен врз фонетска основа (една буква - еден глас) што значително го олеснува составувањето на звучни венци. Во англискиот, пак, дури и да се повторуваат исти фонеми тоа не значи дека исто и ќе звучат, па така во препевот може да се сретнат фонеми кои само ќе создадат визуелна рима, но не и звучна бидејќи фонемата подлежи на звучни промени кога е обиколена со други фонеми. Сепак, не можам да пренебрегнам дека преведувачот се потрудил да долови дел од звучноста на песната преку повторување на гласот $s$ (на англиски) на неколку наврати: 'speed of the stone' (седми стих), 'separating the soul' (осми стих); иако ни приближно како во оригиналот.

Уште еден ритмичен елемент е римата, која се јавува само еднаш во оригиналот и не се среќава во препевот. Станува збор за женска рима на два збора во ист стих (десеттиот): 'тилот од смилот', што е преведено со 'the neck of the immortelle'. Зборот 'immortelle' покрај тоа што се користи за цвет значи и бесмртност, па тоа додава ново значење во стихот. Кај Андреевски, 'тилот од смилот и трендафилот' се врвовите на овие две растенија, односно нивниот цвет, па затоа, во име на римата, би си дозволила да направам поголемо опчекорување од оригиналот, односно смилот да го заменам со друг тип растение кое би се римувало, а сепак би имало некаква заедничка карактеристика со првичниот избор на авторот. Едно од решенијата е да се замени 'immortelle' co 'tansy' кое е растение со жолт цвет исто како и смилот, кај нас познато како вратика. Промена ќе претрпи и зборот $\bar{u} и л о \bar{u}$ (преведен 
како 'neck') кој би го заменила со 'the tip', или врвой на цветот, а крајната верзија на стихот би звучела: 'on the tip of the tansy and the rose' наместо 'on the neck of the immortelle and the rose'.

што иако директно не се римува, сепак создава ритмичност преку збиеноста на едносложните зборови и повторувањето на гласот $t$.

Продолжуваме со матрицата на преводливост преку лексичките очудувања и како тие се пренесени во препевот. Уште во вториот стих наидуваме на предизвик: зборот калемев кој е преведен со 'inserting', зборови кои не се совпаѓаат според регистарот на употреба (стилот). Калеми се користи во ботаниката, кога едно растение се вметнува под кожата на друго за да се добие сортно растение, а преводното решение 'inserting' го доловува ова дејство, но самиот глагол to insert ('вметнува', 'става') е поформален и не се користи во ботаниката. Постои преводен еквивалент кој го запазува регистарот, а тоа е глаголот 'to graft', што во стихот би функционирало како: 'was like grafting light onto darkness'; а згора на тоа, фразата 'to graft onto something' значи поврзување на две нешта кои се дијаметрално спротивставени, како што се во случајов светлината и мракот.

Друг детаљ кој ми го задржа вниманието е употребата на зборот 'transplanting' (односно глаголот to transplant: 'да пренесеш, пресадиш') како превод на македонското вмейнував (глаголот 'вметнува'). Второто значење на transplant е трансплантира, што значи пресадува органи (или ткива) од едно во друго тело и е термин кој се користи во медицината, а во контекст на песната, ја прави целата слика погруба и постерилна. Тоа се спротивставува со топлината која Андреевски ја внесува во зимата и затоа самиот стих си бара потопол, помек глагол кој елегантно би го сместиле наместо сегашниот. Збор кој можеби повеќе би се приближил до оваа нежност е глаголот to enliven ('оживува', 'внесува живост/дух') кој ми се чини прикладен бидејќи го размрдува контрастот помеѓу неживото и живото, односно зимата и летото во стихот кој би звучел вака: 'was like enlivening the winter air with summer air'.

Последните два стиха од третата строфа во препевот сериозно отстапуваат од оригиналот и се алогичности на семантичко рамниште во текстот бидејќи има целосен прекин во смислата поради нивната недопреведност. 'Успаните работници’ од оригиналот не се ни споменуваат во препевот, а тоа ја прекинува телефонската врска помеѓу нивниот сон и раскажувачот за кои зборува Андреевски. Згора на тоа, telephone operator е телефонист (човек кој службено работи на телефон) што го нема во оригиналот; освен ако преведувачот не мислел на буквалниот превод на 'телефонски оператор' што би била уште потрагична грешка. Целата структура и избор на зборови во стиховите на англиски звучат официјално, формално и немаат никаков емотивен багаж, небаре ги опредметуваат чувствата, што воопшто не звучи на Андреевски. Еден од начините на кои можат да се препеат е: 'was like getting phone calls / from sleepy workers' dreams' наместо 'and sleepy telephone operators / were connecting me to dream', каде што се зачувува повторливото како ga и се задржува алитеративното $c$ од оригиналот. 
Песната се гради врз контрасти кои го поддржуваат дихотомскиот пристап

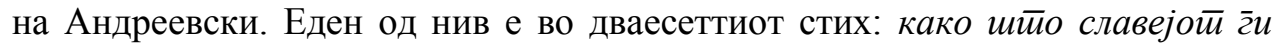
сйријайелуваме небойо и земјайа што се преведени како 'heaven and earth' и се навистина интересен пристап на преведувачот бидејќи му дава нова нијанса на препевот. Алудирам на разликата помеѓу 'sky' и 'heaven' на англиски, зборови кои последователно соодветствуваат на небо и небеса на македонски, а се разликуваат по тоа што небеса има религиозна конотација (местото каде што се наоѓаат Бог и божјите суштества) и тоа додава религиозна нијанса која ја нема во оригиналот. Со ова предвид, спротивноста на 'heaven' би била ‘hell', што ја движи песната во поразлична насока.

Друг пример на лексичко отстапување од оригиналот е преводот на gogeкa co 'and' во дваесет и вториот стих. Сврзникот доgека се користи за поврзување на истовремени дејства во зависносложени реченици што во англискиот јазик би одговарало на 'as' и/или 'while', а стихот би звучел: 'She was taking my weight away / as I was running towards her'.

Пред да преминам на синтаксичкото рамниште на песната ќе споменам последен пример, на самиот крај од песната, во препевот на последната строфа. Лексиката е преформална, скоро правна, како да читаме закон. Зборовите 'participating' и 'establishment' се претешки за вакво финале на песната и непотребно ги отежнуваат националните чувства кои авторот ги изедначува со љубовта кон Дениција. Јордан Плевнеш токму на оваа тема напишал дека „Андреевски е меѓу оние поети што се распознаваат според лицето на земјата што ги родила“" (Андреевски, 1980:19).

За да ја смириме строфата и да го одземеме правно-формалниот карактер на лексиката во препевот, треба да употребиме поедноставни зборови кои сепак ќ ја пренесат смислата на оригиналот, како на пример:

\author{
'Adoring Denicia, \\ was like taking part in the creation \\ of the first Macedonian state.'
}

(непубликуван препев на авторот)

Во поглед на синтаксата во препевот, таа е напати излишно усложнета или нарушена. Еден пример е прекинот на текот на мисла во дваесеттиот стих, каде што во оригиналот мислата продолжува да тече во нова независно сложена реченица, а во препевот таа е прекината со точка и почеток на нова реченица во наредниот стих. Ваквото произволно прекратување на мислата во две (или повеќе) реченици можеби не е страшна отстапка во превод на некнижевен текст, но во книжевен превод (а особено во препевот) додавање на цезура онаму каде што ја нема може сериозно да ја наруши не само певливоста, туку и целосно да ја смени смислата на песната. Во овој случај, прекратена е една најава за метафора и се прекинува текот на целата строфа која, како најдолга, сепак се чита во еден здив во оригиналот. 
Друг пример е отежнатата синтакса и вишокот на зборови во дваесет и четвртиот стих кој е особено едноставен и флуиден во оригиналот. Тешкотијата при читањето на препевот ја создаваат различните форми на двата збора кои ја носат сета тежина на стихот: 'life' и 'dying', кои доколку би ја зачувале формата значително би го олесниле стихот. Еден од начините е: како шимо йаа живееше gоgека јас умирав да се преведе со 'as she lived while I died' наместо со 'as she was full of life while I was dying', со што речиси се преполовува должината на стихот, а повторливоста на наставката '-ed' истовремено го поедноставува и му дава ритам на стихот.

Последно нешто на кое би обрнала внимание е инверзијата на синтаксата во дванаесеттиот стих во оригиналот. Природно би очекувале последователност од типот: „внесував летен воздух во зимниот воздух“, но Андреевски решава да ја очуди синтаксата преку инверзија на именката и заменката на крајот, и така јазикот го претвора во поетски, па добиваме: „внесував летен воздух во воздухот зимен.“ Фактот што ваквата инверзија не се среќава во препевот е можеби најлесна да се прости, од проста причина што англискиот има фиксен збороред и секоја негова инверзија со себе би повлекла додавање на предлози кои би го продолжиле и онака долгиот стих и би ја нарушиле ритмичноста на стихот. Како било, вреди да се напомене дека е очудување во оригиналот кое не се среќава во препевот.

Со посочување на отстапките во оригиналот и препевот на фонолошко, лексичко, синтактичко и семантичко рамниште се приближивме кон недореченото, поетското, кон непреведливото во песната. Љубовта кон Дениција е, сепак, надвор од јазикот и добива нова нијанса која се провлекува кога преведуваме од еден јазик во друг.

\section{4 Одаде и отаде}

„Одаде и отаде“ е елегична песна исполнета со скрб во која се жали прераната загуба на љубената, реалност која неочекувано го затекнала нараторот, кој низ целата песна се обидува да се справи со тегобната ситуација што го снашла. Андреевски со стилска изостреност ги доловува внатрешните, душевни тегоби кои попатно ни создаваат и гнев кон неправедната смрт на некој кој не го изживеал животот. Она што е повторливо во песната е нејзината недореченост и несигурност (особено 15-19 стих) што ни ја открива и незавршената приказна, недореченото помеѓу љубовниците; како целата песна да завршува со три точки кои го прекинале природниот тек и во кои се содржи сѐ што можело да биде. Самиот раскажувач поставува прашања, а од прашања бега. Затоа е важно да се пренесе болката во тонот при преводот на песната на англиски.

Да започнеме со интерпретација на препевот на фонолошко рамниште. Како и во „Кога ја љубев Дениција“, песната ја постигнува ритмичноста преку 
алитеративни венци, анафора, повторување на збор (или негов корен) на ниво на стих, внатрешна и визуелна рима (gава-бара во 13-14 стих).

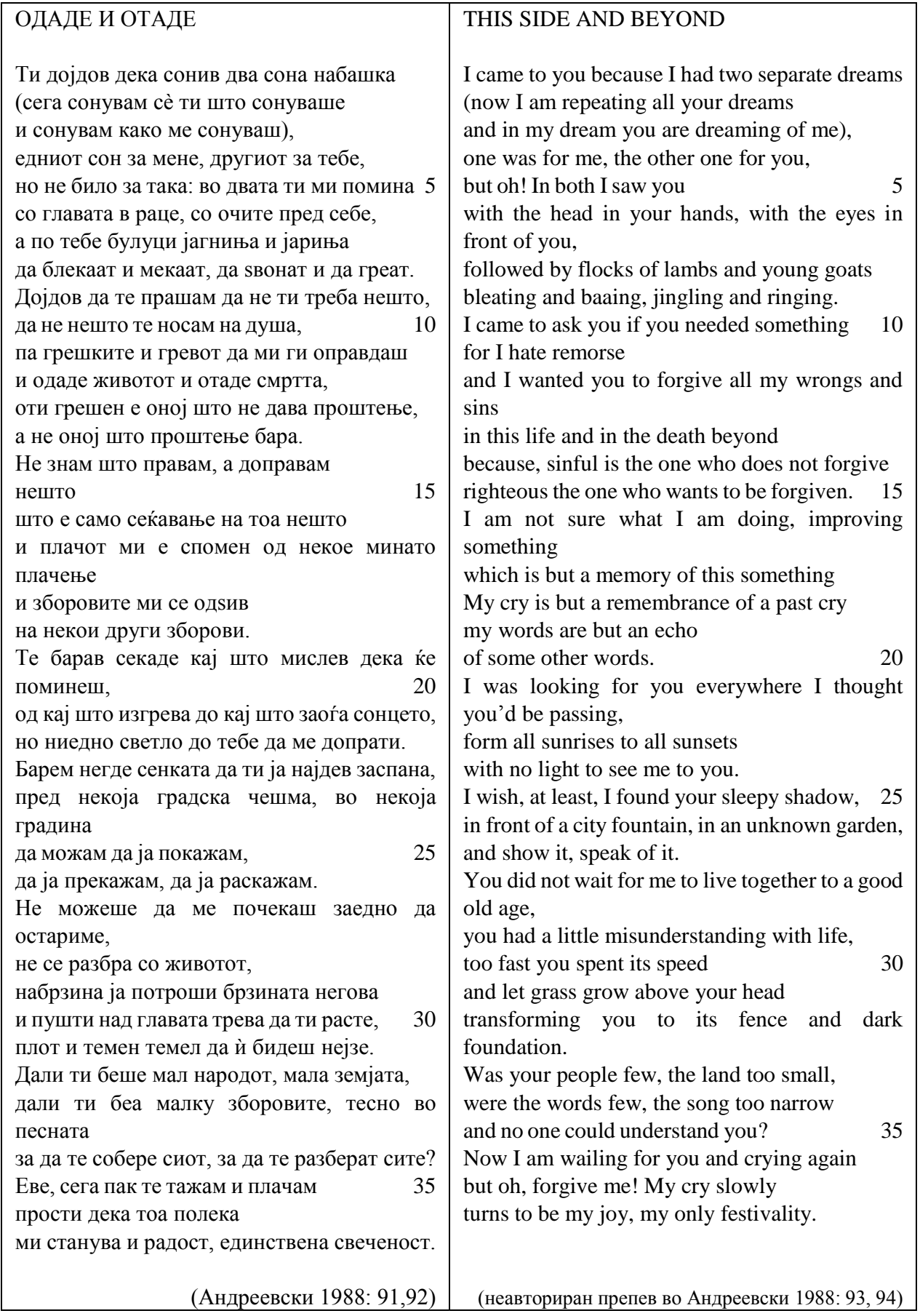


Уште во деветтиот стих наидуваме на ономатопејски елемент кој во комбинација со внатрешна рима (блекаат-мекаат) ја зголемуваат звучноста на

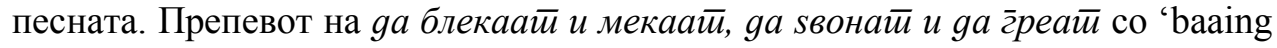
and maaing, bleating and ringing' успешно го има доловено звукот и стихот непречено тече преку истородноста на зборовите (кои завршуваат на -ing), но внатрешната рима не е воочлива. Затоа, може да се направи нов збороред и промена на еден од зборовите со што стихот би ја задржал римата и би звучел вака: 'bleating and baaing, jingling and ringing'.

Во петнаесеттиот и шеснаесеттиот стих, пак, се забележува повторувањето на зборовите 'што' и 'нешто', односно коренот 'што' кој се повторува четирипати во стихот. Фиксната синтакса и лексиката на англискиот ужасно му го отежнуваат обидот на преведувачот да ја пренесе ритмичноста во препевот, но сепак тој донекаде успешно го пренел ритамот преку повторувањето на 'something' на крајот од стиховите. Друг пример се анафората и повторувањето на 'мал' (и варијациите 'мала' и 'малку') во 3335 стих кои не се среќаваат во целост во препевот. Особено во 35-от стих во кој препевот прави поголема отстапка од оригиналот бидејќи не ни пренесува дел од стихот. Едно од решенијата е делумно да се промени стихот за да се задржи и смислата и ритамот, а стиховите да звучат вака:

\section{'were your people few, the land too small, were the words few, the song too tight for you to get in, and be understood?'}

(непубликуван препев на авторот)

што би ја задржала повторливоста на зборовите во стихот и анафората на почетокот, а со промената на 'narrow' во 'tight' се создава алитеративен венец на гласот $t$ кој додава на ритмичноста на стиховите.

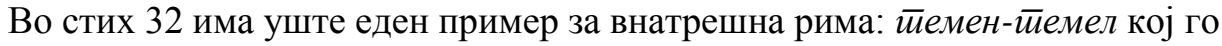
нема во препевот. Преводниот еквивалент му е 'dark foundation' кој не само што не се римува, туку и самиот збор 'foundation' непотребно го оптоварува стихот, кој и онака е значително подолг од оригиналот (исто како и преводот на бuge co 'transforming'). Одбраните зборови се на повисок и поформален регистер кој не звучи поетски и од таа причина предлагам да се промени целиот стих, кој би звучел вака: 'making you its fence and black basis', наместо 'transforming you to its fence and dark foundation' со што 'black' и 'basis' повторно не се римуваат, но барем се создава повторливост на гласот $b$ со што за чекор се приближуваме до оригиналот.

Последниот пример опфаќа и фонолошки и лексички елементи кои го прават совршен за крај на интерпретација на фонолошките и почеток на лексичките очудувања на оригиналот. Зборувам за тринаесеттиот и четиринаесеттиот стих во песната кои не само што се звучно примамливи туку и се стихови кои се симптоми во текстот во однос на нивната тежина. 
Сепак, во препевот не се среќава повторливоста на зборот 'проштење', а преведувачот си зел право и да додаде во препевот нешто што го нема во оригиналот, имено зборот righteous ('правичен', 'праведен'), па така користејќи ги зборовите 'sinful' и 'righteous' создал контраст на место каде што го нема. Од таа причина, едно од можните преводни решенија за овие два стиха би било:

'for sinful is the one who gives no forgiveness, not the one who for forgiveness asks.'

(непубликуван препев на авторот)

На лексичко рамниште има очудување уште на самиот почеток од песната: забележливо е повторувањето на коренот 'сон' кој се повторува седумпати во првите четири стиха во оригиналот, а само четирипати во препевот. Во одредени случаи, секако, ни јазикот ни естетиката не дозволуваат повторување на некој збор по секоја цена, но во случајов верувам дека бројот на повтореното 'сон' во препевот може да е поблизок до оригиналот. Еве еден од начините на кои може да звучат стиховите:

'I came to you because I dreamed to separate dreams

(now I dream all you have dreamed and in my dreams you are dreaming of me), one dream for me, the other one for you,

(непубликуван препев на авторот)

со што основата dream ('сон') се повторува седумпати и се задржува алитеративниот венец на гласот $d$, кој во оригиналот е $c$.

Следната карактеристика е во 25-26 стих во кои основата кажам формира три различни глаголски варијанти (иокажам, ирекажам и раскажам) чие повторување создава ритмичност. Преведувачот направил поголема отстапка од оригиналот при препевот бидејќи не само што превел само две од три форми, туку и во тие две форми не успеал да го задржи истиот корен на зборот. Мојот предлог е коренот кажам да не се замени со друг збор на англиски, туку да се задржи истиот бидејќи самиот јазик нуди можност за тоа, па така, йокажам и ирекажам да станат 'tell' и 'retell'. А бидејќи не најдов преводен еквивалент за раскажам (што е исто со и 'прекажам') кој би ја имал истата основа на англиски ('tell') изнајдов можна визуелна рима, a тоa e utter ('изговара', 'изразува') кој семантички ја задржува смислата на кажам, а гласовите $t$ и $e$ се повторуваат во сите зборови, што ја оправдува нивната последователност. Така, стихот во препев ќе звучи: 'so that I could tell it, / retell it and utter it'.

Во препевот има и неколку зборови кои смисловно не се поклопуваат или пак не одговараат со тонот и регистарот во оригиналот. Еден таков пример е последниот збор од песната, свеченос $\bar{m}$, кој е преведен како 'festivality' и е 
збор кој не постои во англискиот речник. Наместо 'festivality' би требало да се искористат 'festivity' или 'ceremony' како можни преводни еквиваленти. Понатаму, во стих 27 (односно 28 во препевот), оригиналот не се разбра со животиот̄ е преведен 'уоu had a little misunderstanding with life' што звучи тромаво, непоетично и непотребно долго. Именката misunderstanding ('недоразбирање', 'несогласување') може да се замени со 'reconcile with' или 'make peace with', а стихот би звучел: 'уоu didn't reconcile with life' (или 'уou didn't make peace with life') со што стихот би се преполовил по должина и препевот не би звучел буквално преведен. Друг пример е препевот на стих 15: 'Не знам што правам, а доправам нешто' кој е преведен: 'I am not sure what I am doing, improving something'. Проблематичен е преводот на gойравам, бидејќи improving ('подобрува') пред сѐ, подразбира дека нешто претходно не било добро или не исполнувало одредени критериуми па сега се подобрува и со тоа се додава негативна конотација и обоеност на стихот, небаре сѐ што правел нараторот било погрешно. Од таа причина, можеби е посоодветно да се употреби фразата 'finish up' која во стихот би се вклопила како: 'I am not sure what I am doing, finishing up something'.

И за крај, би сакала да посочам неколку отстапки од синтаксичка гледна точка кои се проблематични во однос на препевот. Првата таква отстапка е во стих 28 во препевот (а 27 во оригиналот), каде заеgно gа осйариме е преведено со 'to live together to a good old age'. Непотребно е да коментирам за вишокот зборови кои ја отежнуваат реченицата (три збора се преведени со осум); болната точка е што воопшто не ни станува збор за превод, туку за парафразирање на оригиналот. Наместо кратко и концизно преводно решение, преведувачот решил одоколу да ја нишани метата. Еден од начините да се преведе стихот поинаку е: 'You could not wait for me to grow old together' со што стихот би останал пократок и не би се пресекол за да продолжи во нов стих (како во препевот).

Втората отстапка е во стих 37 во препевот, каде што стихот е произволно прекинат во средина. Тоа ја пресекува мислата која инаку може да се изрази во целина, без да биде поделена на две реченици. Англиското 'but oh, forgive me!' претставува крик кој го нема во оригиналот и дава драмска нијанса на обраќањето. Истото се случува и во петтиот стих каде што повторно е употребено 'but oh!', извик на изненаденост, лутина, разочараност. Ваквите извици значително го менуваат тонот во песната и треба внимателно да ги преведуваме, но само доколку ги има и во оригиналот.

Последен детаљ кој би сакала да го коментирам е бројот на стихови во оригиналот наспрема препевот. Оригиналот брои 37 стиха, а препевот 39. Тоа се должи на парафразата на еден од стиховите која продолжува во нов стих и на напати дескриптивното преведување кое се мачи да држи чекор со збиената, очудена поетска синтакса. Преводот треба да се стреми да биде еднаков по должина со оригиналот бидејќи секое негово продолжување подразбира и разводнување на емоцијата, или пак додавање на нијанси кои ги нема во оригиналот 


\section{5 Нов препев}

Книжевното еволуирање на песната од првичниот во новиот препев се одви преку нејзино комплетно расклопување и одново склопување во кое застарените јазични форми се заменија со нови. Самата матрица на преводливост детално ги истакнува јазичните испреплетувања на фонолошко, лексичко, синтактичко и семантичко рамниште, како гаранција дека литерарноста на Андреевски успешно ќе се пренесе на јазикот-цел. Преводот цели да ги пренесе естетските вредности од македонски на англиски јазик и притоа да ги предизвика истите чувства што ги предизвикал оригиналот во времето на неговото создавање. За појасен увид, препевот на двете песни контрастиран со оригиналот го пренесуваме во целост подолу во текстот.

Новиот препев се стреми да ја допреведе метафизичката нишка во изборот песни на Андреевски иако, во суштина, е само уште едно можно читање и толкување на игривоста на зборовите и значењето кое се крие помеѓу стиховите, а не во нив. Поткрепувањето на новите преводни решенија е аргументирано при самата анализа на првичниот препев, каде што секое очудување е дискутирано и во однос на семантичките нијанси и во однос на новите решенија за тоа како некоја отстапка би можела да се (до)преведе. Притоа, свесна сум дека и нашиот превод отвора нови врати за понатамошни преведувачки дискусии во однос на метафизичката нишка и конотативните нијанси на новите преводни решенија. 


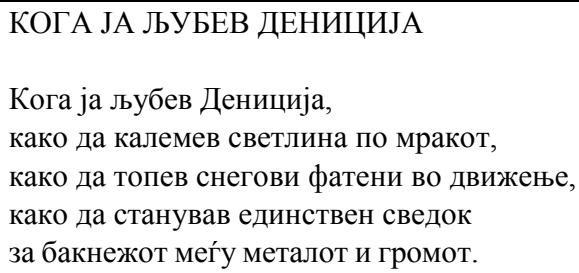

Кога ја љубев Дениција, како да внесував летен воздух во воздухот зимен,

како да ги откривав сите рудници на злато, како да добивав телефонска врска со сонот од сите успани работници.

Оти ја љубев Дениција, како што ги отворав пролетните аптеки, сместени во гласот од славејот, како што славејот ги спријателуваше небото и земјата, како што таа ми ја одземаше тежината, додека трчав кон неа, како што не можев да видам ништо освен неа, како што таа живееше додека јас умирав, како што и јас не знаев како би умрел, ако таа не се родеше.

Кога ја љубев Дениција, како да учествував во создавањето на првата Македонска Држава.

\section{ADORING DENICIA}

Adoring Denicia, was like grafting light onto darkness, was like melting snows caught in motion, was like being the only witness

to the kiss between metal and lightning.

Adoring Denicia,

was like uncovering the speed of stone, was like parting the soul from the body, was like lighting gunpowder on the tip of the tansy and the rose.

\section{Adoring Denicia}

was like enlivening the winter air with summer air,

was like discovering all gold mines, was like getting phone calls

from sleepy workers' dreams.

For I adored Denicia, the way I was opening spring drugstores, set in the voice of a nightingale, the way the nightingale befriended the earth and sky.

She was taking my weight away, as I was running towards her, and I could not see anything but her, as she lived while I died, for I did not know how I would have died, 25 if she had not been born.

Adoring Denicia was like taking part in the creation of the first Macedonian state.

(непубликуван препев на авторот) 


\section{ОДАДЕ И ОТАДЕ}

Ти дојдов дека сонив два сона набашка (сега сонувам сѐ ти што сонуваше и сонувам како ме сонуваш), едниот сон за мене, другиот за тебе, но не било за така: во двата ти ми помина 5 со главата в раце, со очите пред себе, а по тебе булуци јагниња и јариња да блекаат и мекаат, да звонат и да греат. Дојдов да те прашам да не ти треба нешто, да не нешто те носам на душа,

па грешките и гревот да ми ги оправдаш и одаде животот и отаде смртта, оти грешен е оној што не дава проштење, а не оној што проштење бара.

Не знам што правам, а доправам нешто

што е само сеќавање на тоа нешто

и плачот ми е спомен од некое минато плачење

и зборовите ми се одзив

на некои други зборови.

Те барав секаде кај што мислев дека ќе поминеш,

од кај што изгрева до кај што заоѓа сонцето, но ниедно светло до тебе да ме допрати. Барем негде сенката да ти ја најдев заспана, пред некоја градска чешма, во некоја градина

да можам да ја покажам,

да ја прекажам, да ја раскажам.

$\mathrm{He}$ можеше да ме почекаш заедно да остариме,

не се разбра со животот, набрзина ја потроши брзината негова и пушти над главата трева да ти расте, плот и темен темел да ѝ бидеш нејзе.

Дали ти беше мал народот, мала земјата, дали ти беа малку зборовите, тесно во песната

за да те собере сиот, за да те разберат сите?

Еве, сега пак те тажам и плачам

прости дека тоа полека

ми станува и радост, единствена свеченост.

\section{THIS SIDE AND BEYOND}

I came to you because I dreamed two separate dreams

(now I dream all you have dreamed and in my dreams you are dreaming of me), one dream for me, the other one for you, but it would not seem so: in both I saw you 5 with your head in your hands, with a fixed look, with flocks of lambs and young goats behind you,

baaing and maaing, bleating and ringing.

I came to ask you if you needed something, for I hate remorse,

and so you could forgive all my wrongs and sins

in this life and in death beyond,

for sinful is the one who gives no forgiveness not the one who for forgiveness asks.

I am not sure what I am doing, finishing up something

which is but a memory of that something my cry is a recollection of a past cry my words are but an echo of some other words.

I looked for you in every place I thought you'd pass,

from whence the sun rises to where it sets but no light brought me to you.

If only I could find your shadow sleeping,

in front of a city fountain, in a garden,

so that I could tell it, retell it and utter it.

You could not wait for me to grow old together, you did not reconcile with life, and quickly spent its speed and let grass cover your head making you its fence and black basis. Were your people few, the land too small, were the words few, the song too tight for you to get in, and be understood? Now I am bemoaning you and crying again 35 forgive me, for my cry slowly turns to be my joy, my only festivity. 


\section{6 Заклучок}

Како што видовме преку интерпретациите на двата препева на Андреевски, препевот е исклучително детален и креативен процес кој секогаш се стреми кон естетска, а не кон лингвистичка еквиваленција. Поезијата е особено голем предизвик за секој преведувач, „кој со љубов и до детаљ се обидува да ја пренесе смислата на јазикот-цел“ (Михајловски 2002: 330). Самиот Андреевски вели:

Песната, и воопшто уметноста, во својата суштина е пофалба на животот со самото тоа што се јавува во негова заштита, односно во одбрана од смртта. Уметноста е, значи, сведоштво за вечната обнова на животот. [...] Но, и покрај таквото третирање на животот (како апсурд, како негација на самиот себе) сѐ е правено во името на тој живот, и во името на неговото продолжување или пресоздавање. (Андреевски 2007: 5)

Вака гледано, новиот препев е пресоздавање, продолжување на одата на животот, одново раѓање на оригиналот и пренесување на животната искра на јазикот на кој се преведува. Преводот, во суштина, е длабоко херменевтички процес чии конотативни нијанси беа цел на моите интерпретации. Самата природа на преводот постојано бара негово одново освежување и усовршување, па секој нов превод (вклучувајќи го и мојот, и секој иден превод на Андреевски) се стреми за миг да го допре совршеното, да чепне во непреведливото. Овој труд е насочен кон преведување на непреведливото на Андреевски - кон пренесување на метафизичката нишка на избор негови песни, кои се, и ќе продолжат да бидат, ода на животот и на смртта.

За крај, ќе завршам (како и што започнав) со мисла на Драги Михајловски, кој вели: „Зашто најдобрите дела немаат потреба од превод. Тие го содржат во себе“" (Михајловски 2002: 331).

\section{Библиографија}

Андреевски, М. П. (1991). Дениција. Скопје: Наша книга.

Андреевски, М. П. (1988). Никоја gоба. Скопје: Наша книга.

Андреевски, М. П. (1984). Поезија. Скопје: Наша книга.

Андреевски, М. П. (1980). Пииииа йойајница. Скопје: Мисла.

Андреевски, М. П. (2007). Тог̄аш йака реков. Скопје: Штрк.

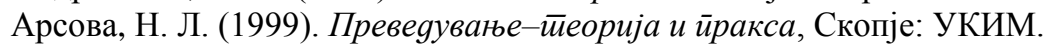

Бенјамин, В. (2002). Задачата на преведувачот [превод на оригинален текст]. Во Д. Михајловски, Поg Вавилон: Заяачайа на йревеgувачоте, 311-341. Скопје: Каприкорнус.

Михајловски, Д. (2002). Поg Вавилон: Заgачайа на йревеgувачой. Скопје: Каприкорнус.

Benjamin, W. (1986). Reflections: Essays, Aphorisms, Autobiographical Writings (1st ed.). Berlin: Schocken. 